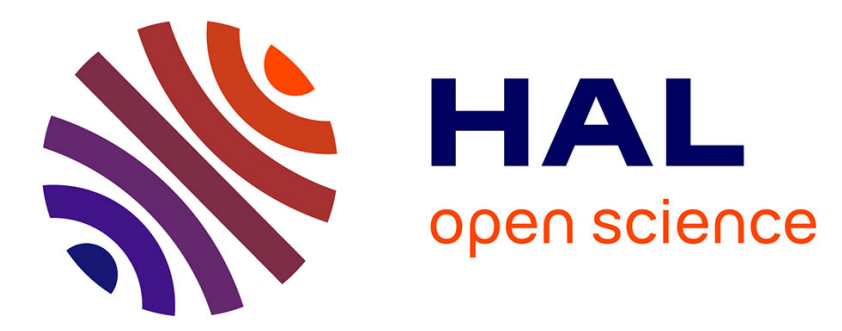

\title{
Differential response to soil drought among co-occurring broad-leaved tree species growing in a 15- to 25-year-old mixed stand
}

\author{
Marion Zapater, Nathalie Bréda, Damien Bonal, Sylvia Pardonnet, André \\ Granier
}

\section{To cite this version:}

Marion Zapater, Nathalie Bréda, Damien Bonal, Sylvia Pardonnet, André Granier. Differential response to soil drought among co-occurring broad-leaved tree species growing in a 15- to 25-year-old mixed stand. Annals of Forest Science, 2012, 70 (1), pp.31-39. 10.1007/s13595-012-0233-0 . hal01201454

\section{HAL Id: hal-01201454 \\ https://hal.science/hal-01201454}

Submitted on 17 Sep 2015

HAL is a multi-disciplinary open access archive for the deposit and dissemination of scientific research documents, whether they are published or not. The documents may come from teaching and research institutions in France or abroad, or from public or private research centers.
L'archive ouverte pluridisciplinaire HAL, est destinée au dépôt et à la diffusion de documents scientifiques de niveau recherche, publiés ou non, émanant des établissements d'enseignement et de recherche français ou étrangers, des laboratoires publics ou privés. 


\title{
Differential response to soil drought among co-occurring broad-leaved tree species growing in a 15- to 25 -year-old mixed stand
}

\author{
Marion Zapater • Nathalie Bréda $\cdot$ Damien Bonal \\ Sylvia Pardonnet • André Granier
}

Received: 3 May 2012 / Accepted: 9 August 2012 / Published online: 6 September 2012

(C) INRA / Springer-Verlag France 2012

\begin{abstract}
- Introduction In the context of global environmental changes, better understanding of tree response to soil drought in young mixed species stands is needed to anticipate forest adaptation and management practices for the future.

- Materials and methods We investigated the functional response of five co-occurring broad-leaved tree species growing in a 15- to 25-year-old mixed stand in northeastern France during the 2006 summer drought. We measured functional traits related to water acquisition (phenology, rooting pattern and vulnerability of xylem to cavitation) and the ecophysiological response (sap flux density, leaf water potential) of these species to soil water shortage. - Results Our study highlights contrasted drought response strategies among these species and a trade-off between leaf phenology, resistance of xylem to cavitation and root system depth.
\end{abstract}

- Conclusion At this site, a deep root system seemed to be a key functional trait for the species to cope with drought. Quercus robur and Salix capreae can be characterised as

Handling Editor: Michael Tausz

Contribution of the co-authors Marion Zapater: in charge of most of the experiment, contributed to the paper writing.

Nathalie Bréda: supervision of the work and writing the paper. Damien Bonal: writing the paper and performing statistical analyses.

Sylvia Pardonnet: in charge of the vulnerability to cavitation (measurements and analyses).

André Granier: supervision of the work and writing the paper

M. Zapater $\cdot$ N. Bréda $\cdot$ D. Bonal $\cdot$ S. Pardonnet $\cdot$ A. Granier $(\bowtie)$

INRA, UMR 1137 INRA-Université de Lorraine,

Forest Ecology and Ecophysiology,

54280 Champenoux, France

e-mail: agranier@nancy.inra.fr

M. Zapater

CRPF Nord Pas-de-Calais Picardie,

96, rue Jean Moulin,

80000 Amiens, France drought-avoidance species as they possess a deep root system and therefore did not strongly experience soil drought. Despite deep rooting capacity, Betula pendula did not really avoid soil drought and strongly regulated transpiration during dry periods. Nevertheless, the earliness of budburst of this species contributes to high annual growth rate. In contrast, Carpinus betulus and Fagus sylvatica both displayed typical characteristics of drought-sensitive species.

Keywords Broad-leaved species · Leaf water potential . Mixed forest · Phenology $\cdot$ Root distribution $\cdot$ Sap flow $\cdot$ Soil drought sensitivity $\cdot$ Vulnerability to cavitation

\section{Introduction}

In the context of global environmental changes accompanied by increasing climatic and biotic hazards (Schär et al. 2004), better understanding of species interactions and forest stand composition is needed to anticipate forest management practices for the future. Coping with increasing climate uncertainties requires forest managers to adapt their sylvicultural practices, particularly by maintaining more natural dynamics and promoting mixed stands at pure stand expense (Lacaze 2000). Indeed, mixed forest stands, through increased biodiversity and ecological niche complementarity, may be more resilient and better able to resist environmental disturbances such as storms, drought, flooding or pest attacks (Bodin and Wiman 2007; Zhang et al. 2012).

Adapting temperate European forest management practices to changing environmental conditions requires being able to characterise the functional responses to disturbance and climatic events of co-occurring tree species under natural conditions, particularly in terms of carbon and water acquisition and use. Most field studies conducted so far in broad-leaved forests have focused on productive, 
economically important species such as Fagus or Quercus (e.g. Bréda et al. 1993a, 1995, 2006; Coners and Leuschner 2002; Leuschner et al. 2004; Granier et al. 2007). Only a few studies have included one or more accompanying species (Pataki et al. 2000; Holscher et al. 2005; Leuzinger et al. 2005; Kocher et al. 2009). A comprehensive study pointing out potential trade-offs among co-occurring species for water uptake, water transport or transpiration regulation during a summer drought has not yet been conducted. In this study, we investigate this issue in a mixed broad-leaved stand with five co-occurring species in northeastern France where soil water content is often reduced during summer.

Different drought tolerance or resistance strategies are well-known for xeric species in arid habitats (Kramer 1983). For temperate broad-leaved forests, Kramer (1983) described three contrasted responses to soil drought. Firstly, avoidance: some species are able to avoid reduced soil water content during drought periods by a temporal shift in phenology such as early budburst in spring (e.g. Gould et al. 2011) or by relying on deep root systems to access deep wet soil layers (e.g. Zapater et al. 2011). Secondly, tolerance: some species are able to delay drought impact, through delayed stomatal closure and the ability to maintain high photosynthetic activity despite low leaf water potential (e.g. Cedrus species, Aussenac and Finkelstein 1983). Thirdly, dehydration tolerance: some species implement efficient osmotic adjustments under soil water depletion that allow them to maintain high water potential levels for photosynthesis and summer growth (Hsiao et al. 1976). The identification of these different strategies should not obscure the likelihood that broad-leaved temperate tree species undergo a continuum of responses to drought. Furthermore, the coexistence of certain tree species in mixed stands may be explained by niche differentiation among species (Tilman 1982). It is thus worthwhile to investigate the role of water resource partitioning in the growth performance of mixed temperate forest species submitted to severe summer drought, as such extreme conditions will increasingly occur under global environmental changes (Granier et al. 2007).

In this context, the aim of the present study was to highlight drought response strategies among five cooccurring broad-leaved tree species growing in a 15- to 25-year-old mixed temperate forest northeastern France. The studied species-Betula pendula, Carpinus betulus, Fagus sylvatica, Quercus robur, Salix capreae-cover a wide successional forest gradient. We investigated functional traits related to water acquisition (phenology, rooting pattern and vulnerability of xylem to cavitation) and the ecophysiological response of these species to soil water shortage. Furthermore, we identified whether potential functional trait combinations and trade-offs exist among the species and whether these trade-offs were consistent with the three above-mentioned strategies.

\section{Materials and methods}

\subsection{Study site}

The study was carried out in a young 15-ha mixed broadleaved stand in the state forest of Hesse (France, 48 $40^{\prime} 27^{\prime \prime}$ $\mathrm{N} ; 7^{\circ} 03^{\prime} 53^{\prime \prime} \mathrm{E}$, elevation $305 \mathrm{~m}$ ). The climate is semicontinental with a mean annual temperature of $9.2^{\circ} \mathrm{C}$ and mean annual precipitation of $820 \mathrm{~mm}$. The soil is a mesosaturated neoluvisol redoxisol. A clear shift in soil structure and texture can be noticed in the transition between the E2 (eluviated) and the BT horizons at approximately $0.50 \mathrm{~m}$ in depth. The less permeable BT horizon is enriched in clay (clay content up to $31 \%$ ) and presents a prismatic structure. Periods of low rainfall during the summer can lead to substantial water shortage in the upper soil layers whereas late spring rainfall can induce periods of water-logging.

The study stand is composed of 15- to 25-year-old naturally regenerated trees including, from the most to the least abundant tree species: European beech (F. sylvatica), hornbeam (C. betulus), oaks ( $Q$. robur), goat willow ( $S$. capreae), silver birch (B. pendula), aspen (Populus tremula) and wild cherry (Prunus avium). In 2002, stand basal area was $12.6 \mathrm{~m}^{2} \mathrm{ha}^{-1}$ and stand density was 17,820 . Contribution of each species to stand basal area was $63 \%$ for beech, $26 \%$ for hornbeam and $7 \%$ for oaks (Le Goff and Ottorini, personal communication). The other species represented ca. $4 \%$.

Measurements were conducted in a $1,600-\mathrm{m}^{2}$ plot located near the middle of the stand and surrounded by a fence. The fenced plot was equipped with three 10- to 14-m-high scaffolding towers, allowing access to the sun-exposed branches of each studied tree. Measurements were performed during the summer of 2006 except those concerning the vulnerability to cavitation that were recorded during the 2007 summer. In the fenced plot, leaf area index, estimated using a Li-2000 leaf area meter (Li-Cor, Lincoln, NE, USA) was $7.60 \pm 0.08$ in 2006 and $7.55 \pm 0.12$ in 2007 .

\subsection{Microclimate}

To characterise the microclimatic conditions during the study period, the following instruments were installed in the stand at a height of $14 \mathrm{~m}$ : a pyranometer (CM6, Kipp \& Zonen), a rain gauge (Model ARG 100, Campbell Scientific, Courtaboeuf, France), a temperature and relative humidity probe (HMP45 model Vaisala, Helsinki, Finland) and an ultrasonic 3D anemometer (Solent R3 Windmaster, Gill Instruments Ltd., Lymington, UK). Data were acquired every $10 \mathrm{~s}$, and 30 -min averages were stored in a datalogger (CR5000, Campbell Scientific, Courtaboeuf, France). Penman evapotranspiration (PET) was calculated using the Penman formula. 


\subsection{Tree sampling}

Four dominant or co-dominant trees were randomly selected for B. pendula, C. betulus, $Q$. robur and $S$. capreae and six trees for F. sylvatica (Table 1). The trees vary little in total height and diameter at breast height. Characteristics of the studied trees are given in Table 1.

\subsection{Soil water content}

Available soil water at the stand scale was estimated daily with the BILJOU water balance model (Granier et al. 1999). This model uses daily climatic data, as measured above the stand, and site parameters - mainly leaf area index, leaf unfolding dates, leaf fall dates, maximum extractable soil water in the root zone, vertical root distribution and soil macro- and micro-porosity. From the simulated daily soil water content in the rooting zone (down to $1.5 \mathrm{~m}$ in depth), we calculated the daily relative extractable soil water (REW; i.e. the standardized available soil water) as follows:

$\mathrm{REW}=\mathrm{EW} / \mathrm{EW}_{0}$,

where EW is the actual extractable soil water in the rooting zone and $\mathrm{EW}_{0}$ is the maximum available water, i.e. the difference in soil water content between field capacity and the minimum water content. EW was equal to $175 \mathrm{~mm}$ down to $1.5 \mathrm{~m}$ in depth. REW varies between 1 (at field capacity) and 0 (at the permanent wilting point, i.e. $-1.6 \mathrm{MPa}$ ). In this study, REW was taken as an indicator of soil water availability at plot scale, not at tree level.

\subsection{Sap flow measurements}

Sap flow was monitored with 20-mm-long thermal dissipation sensors (Granier 1985) radially inserted in the xylem at breast height on the 22 studied trees (Table 1), with one sensor per tree. This technique makes it possible to measure sap flux density (SFD, i.e. the sap flow per unit of sapwood area, in $\mathrm{L} \mathrm{dm}^{-2} \mathrm{~h}^{-1}$ ), integrated along the 20 -mm radial axis. Sensor signals were sampled at 10 -s intervals, averaged

Table 1 Number of replicates $(n)$, mean diameter at breast height $(\mathrm{DBH})$ and mean height $(H)$ of the studied tree species

\begin{tabular}{llll}
\hline Tree species & $n$ & DBH $(\mathrm{cm})$ & $H(\mathrm{~m})$ \\
\hline Betula pendula & 4 & $6.45(0.83)$ & $8.95(0.34)$ \\
Carpinus betulus & 4 & $6.13(1.33)$ & $8.35(0.13)$ \\
Fagus sylvatica & 6 & $8.58(1.29)$ & $8.47(0.45)$ \\
Quercus robur & 4 & $8.28(1.03)$ & $8.45(0.54)$ \\
Salix capreae & 4 & $7.68(2.36)$ & $9.25(0.59)$ \\
\hline
\end{tabular}

Standard deviation is indicated in brackets. All trees belong to dominant and co-dominant crown classes every $30 \mathrm{~min}$ and stored in two data loggers (Campbell Scientific, models CR 10 and CR 21X, Courtaboeuf, France). Data were collected during the growing season, from mid June (day of year (DOY) 164) to mid September (DOY 258), 2006.

The daily sap flux density of each tree was calculated as the sum of 0.5-h SFD values. We defined maximum seasonal sap flux density $\mathrm{SFD}_{\max }$ for each species as the mean value of daily sap flux density under non-limiting soil water availability, i.e. from DOY 165 to 194. For each species, we calculated the variability of sap flux density within each species. Over the whole measurement period, coefficients of variation (= $100 \times$ mean/standard deviation) were low, ranging from $2.5 \%$ in F. sylvatica to $7.8 \%$ in S. capreae. Daily relative sap flux density (SFD\%) for each tree was then calculated as the ratio of daily sap flux density to $\mathrm{SFD}_{\max }$.

\subsection{Leaf water potential}

Predawn ( $\left.\Psi_{\mathrm{wp}}, \mathrm{MPa}\right)$ and midday $\left(\Psi_{\mathrm{wm}}, \mathrm{MPa}\right)$ leaf water potentials were measured on two to five leaves for each tree with a Scholander-type pressure chamber (PMS instrument, Corvallis, OR, USA). We checked that ambient air was close to saturation $(H>98 \%)$ during $\Psi_{\mathrm{wp}}$ measurements. $\Psi_{\mathrm{wm}}$ measurements were performed between 1000 and 1400 hours UT. $\Psi_{\mathrm{wp}}$ and $\Psi_{\mathrm{wm}}$ were measured on, respectively, four and five different dates.

\subsection{Phenological observations}

Leaf unfolding and leaf fall observations were made on the targeted trees two to three times a week from mid March to the end of May and from October to the end of November. An additional five to 16 trees per species were also observed to ensure better species pattern characterisation. Bud development was described on a six- to eight-stage scale (Bréda and Granier 1996) depending on the species (dormant winter buds, swollen buds, broken buds, just unfolding leaves, unfolded leaves, developed leaves with elongation twigs and intermediate stages for some species). Leaf fall was described through four steps according to leaf yellowing and fall.

\subsection{Xylem vulnerability curves to cavitation}

Xylem vulnerability curves to cavitation were established on excised, sun-exposed, current-year shoot internodes. In order to avoid damage to trees where sap flow was measured, branches were sampled from nearby trees with dominant crown status. We collected sun branches from three trees of each species in August and September for B. pendula, C. betulus and S. capreae and between mid-July and the end of August for the other species. Before cutting the branches, water was sprayed onto the leaves in order to minimize transpiration. The branches 
were cut rapidly, then re-cut under water and enclosed in airtight black plastic bags, with the basal ends immerged in water. Then, they were transported to the laboratory as quickly as possible for measurements. The air injection method was used to induce cavitation and embolism (Cochard et al. 1992). The degree of embolism was assessed by measuring the loss of hydraulic conductance caused by air blockage in the xylem conduits of the short branch internodes (Cochard et al. 1992). In a pressure chamber (PMS instrument, Corvallis, OR, USA), the branches ( 0.15 to $0.30 \mathrm{~m}$ long) were submitted to a progressive decrease in xylem water potential by pressurisation with stepwise pressure increments until sap exudation ceased. They were then enclosed in a black airtight bag for at least $5 \mathrm{~h}$ to remove water potential gradients between leaves and xylem tissues. Five to ten shoot internodes ( 0.008 to $0.015 \mathrm{~m}$ long) of each branch were then excised under water and the initial hydraulic conductance $\left(K_{\mathrm{i}}\right.$, in mmol s $\left.\mathrm{MPa}^{-1}\right)$ was measured by perfusing a solution $\left(\mathrm{KCl} 10 \mathrm{mM} ; \mathrm{CaCl}_{2} 1 \mathrm{mM}\right)$ at $3.5 \mathrm{kPa}$ pressure. The solution rate flowing through each sample was measured (in mmol s-1) with a Xyl'EM device (Xylem Embolism Meter, Instrutec, Montigny les Cormeilles, France). The maximum hydraulic conductivity $\left(K_{\max }\right)$ was obtained after embolism removal by flushing with the solution at a higher pressure (0.1 MPa) until hydraulic conductance no longer increased. The percentage loss of conductivity (PLC) was calculated as follows:

$\mathrm{PLC}=100 \times\left(1-\frac{K_{\mathrm{i}}}{K_{\max }}\right)$.

The following sigmoid-type function was fitted to each data set:

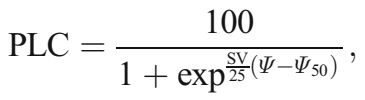

where $\Psi_{50}$ is the pressure inducing $50 \%$ loss of conductivity, $\mathrm{SV}$ is the slope at the xylem water potential value $\Psi_{50}$ and $\Psi$ is the actual xylem water potential.

\subsection{Root distribution}

In order to circumvent the problem of root identification, dominant and co-dominant trees of the studied species were chosen in mono-specific clusters located in the study stand as close as possible to the fenced plot. To study root distribution both vertically and tangentially to the tree stems, we used the 2D root mapping technique from soil trenches. Trenches of about $0.75 \mathrm{~m}$ wide, $2.40 \mathrm{~m}$ long and 1.50 to $1.70 \mathrm{~m}$ in depth were dug tangentially to the stems at a distance of approximately 0.25 to $0.65 \mathrm{~m}$, where most of the fine roots are usually found (Thomas and Hartmann 1998). An observation plane (a vertical area of ca. $3.6 \mathrm{~m}^{2}$ per tree) was cleaned with a knife just before counting the number of fine roots (diameter $<3 \mathrm{~mm}$ ) crossing each $0.10 \times 0.10 \mathrm{~m}$ square of a $0.60 \times 0.60-\mathrm{m}$ metal grid; only living fine roots were counted. The number of roots counted in each $0.10 \times$ $0.10 \mathrm{~m}$ square was averaged for each $0.1 \mathrm{~m}$ deep soil layer over the entire soil profile (i.e. over ca. $0.24 \mathrm{~m}^{2}$ ) and then converted into either total fine root density (down to $1.20 \mathrm{~m}$ ) (RD) or root density below the depth of change in soil texture (ca. $0.50 \mathrm{~m}$ depth) $\left(\mathrm{RD}_{\mathrm{b}} \%\right)$.

\subsection{Statistical analyses}

Between-species differences in functional traits were tested with "PROC GLM" followed by a Tukey range test with SAS software (SAS 9.0, SAS Institute, Cary, NC, USA). Fitted parameters of the vulnerability curves were obtained with Statgraphics Plus for Windows 4.1 (Statistical graphics Corp., Herndon, VA, USA). A principal component analysis was performed on variables involved in the response of the studied species to soil drought in order to explore whether these species would display similar or different response strategies. The variables injected into this analysis were either related to the drought intensity experienced by the trees $\left(\Psi_{\mathrm{wp}}, \Psi_{\mathrm{wm}}, \mathrm{SFD} \%\right.$ and $\left.\mathrm{RD}_{\mathrm{b}} \%\right)$ or characterised vulnerability to cavitation ( $\Psi_{50}$ and Slope) or earliness of the growing season (leaf unfolding date). The analysis was done with the SAS software. We used the "PROC CLUSTER" options in SAS (i.e. cubic clustering criterion, the pseudo- $F$ statistic, and the pseudo $t^{2}$ statistic) to detect any clusters of trees after the principal component analysis had been performed.

\section{Results}

\subsection{Phenology}

Leaf unfolding and leaf fall showed large differences in time-course among species, up to 12 and 18 days, respectively (Fig. 1). The growing season started earlier for $B$. pendula (DOY 111) and C. betulus (DOY 112) than for $Q$. robur (DOY 123) and F. sylvatica (DOY 121). Though slightly shorter for B. pendula (169 days), the average length of the growing season was rather similar among species, i.e. 175 days ( \pm 5 days) (Table 2 ).

\subsection{Leaf water potential and sap flow measurements}

In northeastern France, the summer of 2006 was characterised by a drought period in July (Fig. 2a). From June to the middle of July (DOY 190), when REW was still high ( $>0.6$ ), the variation in SFD\% followed that of PET for all studied species. Stand-scaled transpiration, as calculated from sap flux density measurements and estimated sapwood area of each studied species, reached a maximum rate of $2.8 \mathrm{~mm}$ 
Fig. 1 Mean time course of budburst (left) and leaf fall (right) during 2006 of the five studied tree species. Vertical bars indicate standard error
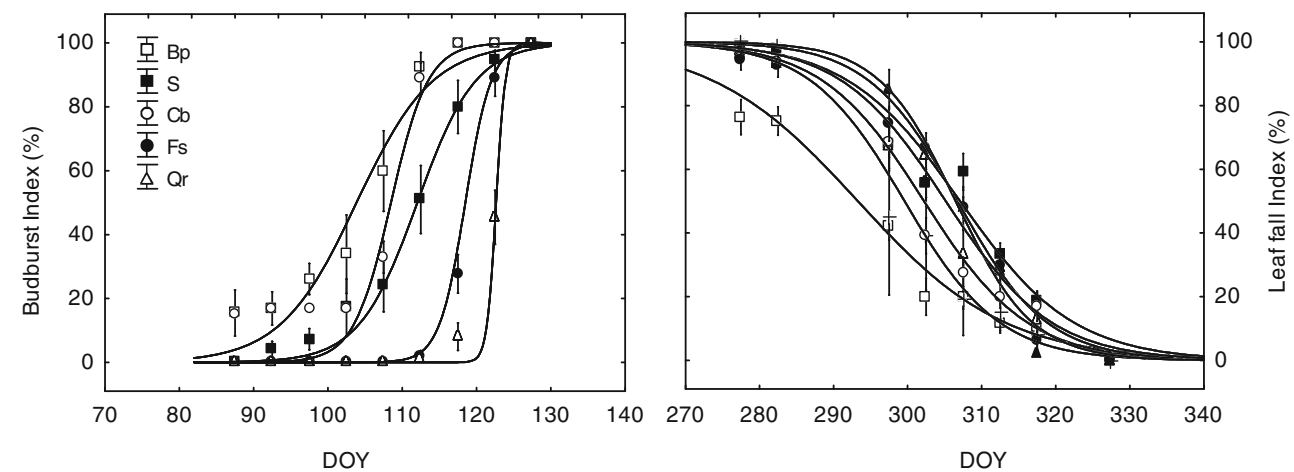

day $^{-1}$. Thereafter, when REW decreased below 0.4 , the time courses of SFD\% diverged among species and they displayed contrasted transpiration and $\Psi_{\text {wp }}$ (Fig. 2a, b). B. pendula, $C$. betulus and $F$. sylvatica showed a strong reduction in SFD\% and $\Psi_{\mathrm{wp}}$, while $Q$. robur, and to a lesser extent $S$. capreae, did not show any major change in these variables (Fig. 2). The drop in SFD\% first occurred in B. pendula, followed by $F$. sylvatica and then $C$. betulus. At the end of the dry period, $\Psi_{\mathrm{wp}}$ ranged from $-0.52 \mathrm{MPa}$ for B. pendula to $-1.45 \mathrm{MPa}$ for $C$. betulus and F. sylvatica. In all species, $\Psi_{\mathrm{wm}}$ also decreased from about -1.25 to -1.50 to about -1.90 to $-2.25 \mathrm{MPa}$, except for $B$. pendula which exhibited rather stable values all along the summer (around $-1.35 \mathrm{MPa}$ ).

\subsection{Fine root distribution}

All species displayed a sharp decrease in fine root density from the soil surface to a depth of $0.5-0.6 \mathrm{~m}$ (Fig. 3). This decrease was strongly related with the increase in bulk soil density $\left(r^{2}\right.$ ranged from 0.87 for B. pendula to 0.99 for C. betulus) (Table 3). Total fine root density (down to $1.20 \mathrm{~m}$ ) and root density below $0.50 \mathrm{~m}$ depth revealed large interspecific differences (Table 3); for example, $C$. betulus had $30 \%$ more roots than $F$. sylvatica. From higher to the lower root densities, the species ranked as follows: $C$. betulus $>$ B. pendula $>$ Q. robur $>$ $S$. capreae $>F$. sylvatica. Large interspecific differences were also observed in the proportion of deep fine roots: $B$. pendula and $Q$. robur had the highest fine root densities below the clayenriched layer (40 and $33 \%$, respectively, Table 3), while $F$.

Table 2 Mean leaf unfolding and leaf fall dates (day of the year) and length of the growing season (in days) in 2006 for the studied tree species

\begin{tabular}{llll}
\hline Tree species & $\begin{array}{l}\text { Unfolding } \\
\text { date }\end{array}$ & $\begin{array}{l}\text { Leaf fall } \\
\text { date }\end{array}$ & $\begin{array}{l}\text { Growing } \\
\text { season length }\end{array}$ \\
\hline Betula pendula & 111 & 280 & 169 \\
Carpinus betulus & 112 & 293 & 181 \\
Fagus sylvatica & 121 & 298 & 177 \\
Quercus robur & 123 & 295 & 172 \\
Salix capreae & 117 & 291 & 174 \\
\hline
\end{tabular}

sylvatica and $C$. betulus had only 23 and $15 \%$, respectively. It is noteworthy that there was no significant relationship between total root density and deep root proportion (Table 3; Fig. 3).

\subsection{Vulnerability to cavitation}

All vulnerability curves had a typical sigmoid shape and were well-fitted to the function in Eq. 1. There was a significant species effect on the $50 \%$ loss in xylem conductivity $\left(\Psi_{50}\right)$ and intraspecific variability was very low (data not shown). $\Psi_{50}$ of $S$. capreae, the most vulnerable tree
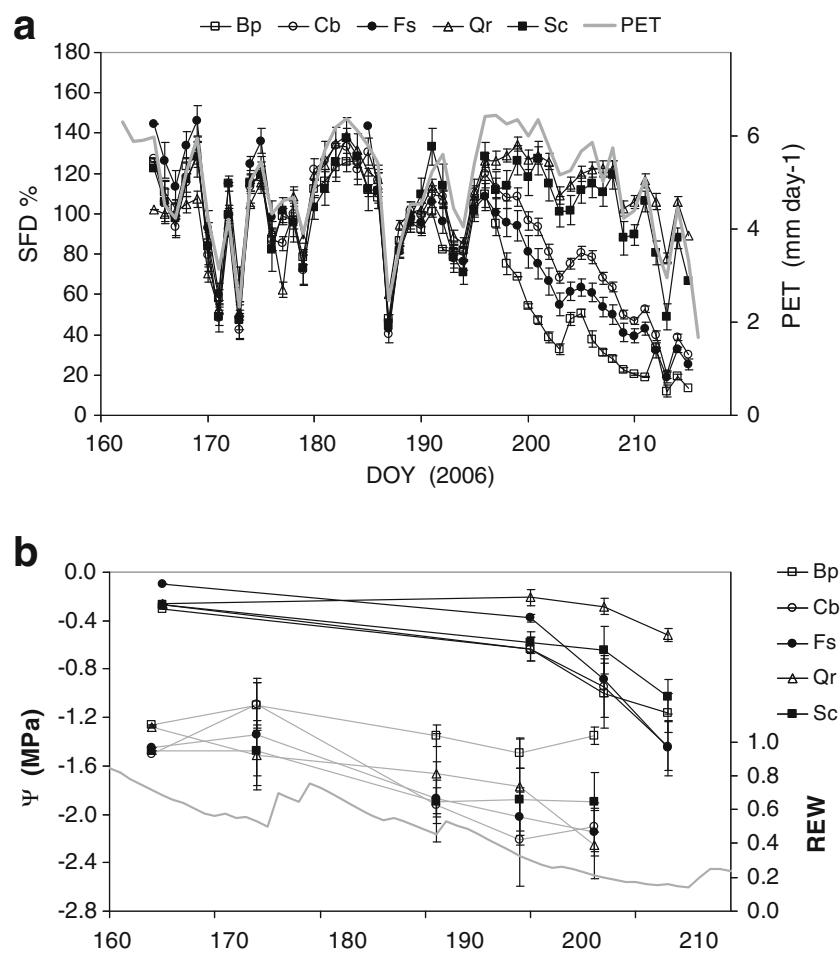

Fig. 2 a Time course of the daily relative sap flux density (SFD\%) and the potential evapotranspiration (PET; Penman formula) for the studied tree species studied in 2006. Symbols correspond to species: $B p, B$. pendula; Cb, C. betulus; Fs, F. sylvatica; Qr, Q. robur; Sc, S. capreae. b Predawn leaf water potential (black symbols, $\Psi_{\mathrm{wp}}$; left vertical axis), midday leaf water potential (grey symbols, $\Psi_{\mathrm{wm}}$; left vertical axis) and relative extractable soil water (grey line, REW; right vertical axis) in summer 2006. Vertical bars indicate standard error 


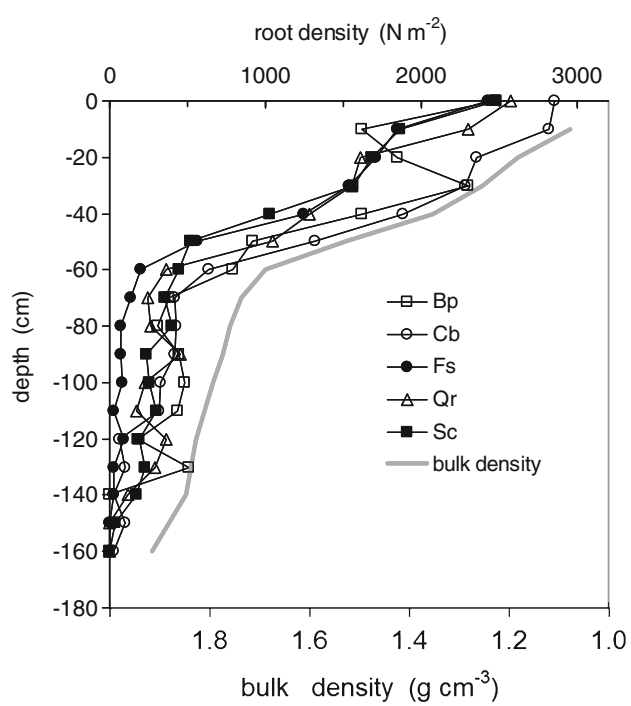

Fig. 3 Bulk soil density (grey line) and fine root (diameter $<3 \mathrm{~mm}$ ) density distribution $\left(\mathrm{N} \mathrm{m}^{-2}\right)$ of the six investigated tree species above $1.60 \mathrm{~m}$ in depth. Symbols correspond to species: Bp, B. pendula; $C b, C$. betulus; Fs, F. sylvatica; Qr, Q. robur; Sc, S. capreae

species, was $-1.6 \mathrm{MPa}$ and that of the least vulnerable, $C$. betulus, was $-3.6 \mathrm{MPa}$. The species also displayed large differences in the slope at the inflection point: from 30 to $130 \% \mathrm{MPa}^{-1}$. No significant relationship between slope and $\Psi_{50}$ was found ( $p$ value $\left.=0.264\right)$.

\subsection{Principal component analysis}

The first two axes of the principal component analysis explained $85.2 \%$ of the observed variability (Fig. 4a). The first axis explained $50.0 \%$ of the total variance and was strongly negatively correlated with budburst date and positively correlated with control of embolism (Slope), midday leaf water potential $\left(\Psi_{\mathrm{wm}}\right)$ and percentage of roots below $0.5 \mathrm{~m}\left(\mathrm{RD}_{\mathrm{b}} \%\right)$. The second axis explained $35.2 \%$ of the total variance and was positively correlated with intensity of drought experienced by trees $\left(\Psi_{\mathrm{wp}}\right)$, stomatal control of transpiration (SFD\%), vulnerability to xylem cavitation $\left(\Psi_{50}\right)$ and $\mathrm{RD}_{\mathrm{b}} \%$.

Table 3 Total root density (RD, i.e. the number of fine roots per $\mathrm{m}^{2}$ of vertical plane down to $1.20 \mathrm{~m}$ in depth), root density below the depth of change in soil texture (ca. $0.50 \mathrm{~m}, \mathrm{RD}_{\mathrm{b}}$ ), percentage of roots below this depth $\left(\mathrm{RD}_{\mathrm{b}} \%\right)$, and correlation coefficients $\left(r^{2}\right)$ of relationships between bulk soil density and RD for the studied tree species

\begin{tabular}{llccc}
\hline Tree species & $\mathrm{RD}$ & $\mathrm{RD}_{\mathrm{b}}$ & $\mathrm{RD}_{\mathrm{b}} \%$ & $r^{2}$ \\
\hline Betula pendula & 14,988 & 5,949 & 40 & 0.87 \\
Carpinus betulus & 16,363 & 3,786 & 23 & 0.99 \\
Fagus sylvatica & 10,046 & 1,533 & 15 & 0.98 \\
Quercus robur & 12,871 & 4,194 & 33 & 0.97 \\
Salix capreae & 11,733 & 3,912 & 33 & 0.96 \\
\hline
\end{tabular}
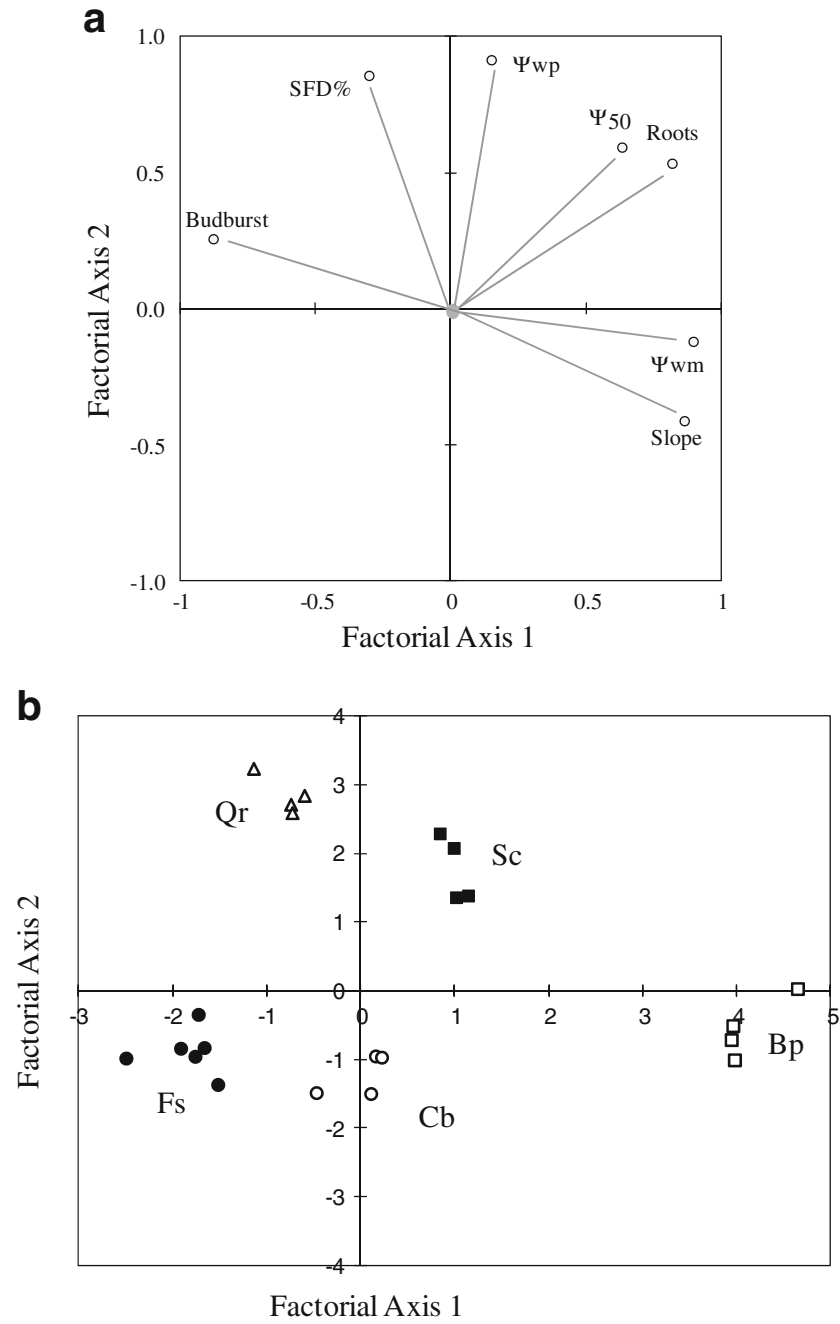

Fig. 4 Principal component analysis for the trees of the five studied species, according to seven variables characterising or involved in drought response: (1) variables related to drought intensity experienced by the trees ( $\Psi_{\mathrm{wp}}, \Psi_{\mathrm{wm}}, \mathrm{SFD} \%$, depth of root system), (2) variables characterising vulnerability to cavitation ( $\Psi_{50}$, Slope) and (3) earliness of the growing season (budburst date). $\Psi_{\mathrm{wp}}$ and $\Psi_{\mathrm{wm}}$ were measured at the driest time of the 2006 summer, i.e. DOY 213 and 206, respectively. a Projection of the studied variables on the first factorial plane. b Projection of the trees on the same plane; each data point is one tree. Symbols correspond to species: Bp, B. pendula; $C b, C$. betulus; $F s, F$. sylvatica; $Q r, Q$. robur; $S c, S$. capreae

On this factorial plane, the trees of a given species were clearly aggregated (Fig. 4b). Furthermore, the statistical options of the CLUSTER analysis revealed five clusters of trees in our data that correspond exactly to the five studied species (Fig. 4b).

\section{Discussion}

In summer 2006, reduced rainfall and high evapotranspiration in the experimental plot induced a decrease in modelled 
REW to below the threshold of 0.4, which is known to induce stomatal closure and a decrease in canopy conductance for most temperate tree species (Granier et al. 1999). However, we observed contrasted functional responses among the co-occurring species we investigated: B. pendula, $C$. betulus and $F$. sylvatica experienced severe water stress, with a strong decrease in both their transpiration and predawn leaf water potential (Fig. 2). On the contrary, Q. robur, and to a lesser extent $S$. capreae, did not experience water stress (low or no decrease in predawn leaf water potential) and maintained high transpiration rates. Such a contrasted response to drought among co-occurring trees had previously been reported during the 2003 drought in a mature mixed hardwood forest including Quercus petraea, F. sylvatica and C. betulus by Leuzinger et al. (2005) and in a companion study conducted at the same site in 2008 on Q. robur and F. sylvatica by Zapater et al. (2011). In the latter study, performed in the same experimental site during the following year, the hydraulic lift phenomenon was evidenced, leading to soil water redistribution in such mixed stand.

With the exception of $B$. pendula, we confirmed that for this broad-leaved mixed stand the species that develop deep rooting systems efficiently postpone, or even avoid, the effects of reduced upper soil water availability (Bréda et al. 1995). Indeed, for $Q$. robur and $S$. capreae, the absence of a decrease in predawn leaf water potential and transpiration regulation is largely explained by the depth of their root system (Fig. 3; Table 3), whereas the strong decrease in transpiration for $C$. betulus and F. sylvatica was consistent with a shallow rooting system.

With regards to plant survival to drought, the importance of preventing hydraulic failure in the soil-plant-atmosphere continuum has been extensively studied (Sperry et al. 2002; McDowell et al. 2008). Hydraulic failure occurs when reduced soil water availability, coupled with high evaporative demand, leads to cavitation. Our estimates of $\Psi_{50}$ are close to those of previous studies on broad-leaved temperate species (e.g. Bréda et al. 1993b; Tyree and Cochard 1996; Cochard et al. 1999). Strong differences among tree species in both $\Psi_{50}$ and slope were found (Table 4), with low

Table 4 Parameters characterising the vulnerability to cavitation of the studied tree species: values of $\Psi_{50}$ (i.e. the water potential inducing a $50 \%$ loss in hydraulic conductivity) and the slope of drought-induced cavitation variation at $\Psi_{50}$

\begin{tabular}{lcc}
\hline Tree species & $\Psi_{50}(\mathrm{MPa})$ & Slope $\left(\% \mathrm{MPa}^{-1}\right)$ \\
\hline Betula pendula & $-1.84(0.02)$ & $139.4(15.7)$ \\
Carpinus betulus & $-3.64(0.17)$ & $101.5(32.0)$ \\
Fagus sylvatica & $-3.25(0.02)$ & $46.9(4.4)$ \\
Quercus robur & $-2.62(0.05)$ & $48.1(3.4)$ \\
Salix capreae & $-1.60(0.07)$ & $80.4(9.2)$ \\
\hline
\end{tabular}

intraspecific variability. We observed that $\Psi_{50}$ and the depth of the root system were located close together on the principal component analysis plane (Fig. 4a), thus indicating for the studied species that the deeper the fine roots, the less negative $\Psi_{50}$. Furthermore, some studies had previously reported that $\Psi_{50}$ could be related to stem wood density (Hacke et al. 2001). Our results thus suggest for these species a trade-off in carbon allocation to the different tissues of the plant: when more carbon is invested in branch xylem to protect xylem elements against cavitation (Hacke et al. 2001), less carbon can then be invested in the root system to explore deeper and wetter soil layers. Sperry and Hacke (2002) and Hukin et al. (2005) previously mentioned such a trade-off for plants growing in xeric habitats.

The slope of the vulnerability curves at $\Psi_{50}$ is assumed to be linked to xylem heterogeneity, i.e. the variability in vulnerability to cavitation inside water conducting elements making up the xylem (Pammenter and Vander Willigen 1998). For our species, the slope was correlated with midday leaf water potential $\left(r^{2}=0.66\right)$ and to a lesser extend with the SFD \% reached during the driest period $\left(r^{2}=0.28\right)$. These relationships further point to interesting strategies in terms of drought avoidance and preservation from embolism: species like $B$. pendula and $C$. betulus that display a steep cavitation slope are also characterised by a high degree of stomatal regulation (decrease in SFD\%) when soil drought increases, thus protecting the xylem from cavitation. Nevertheless, this pattern was not observed for $F$. sylvatica, which also displayed a strong reduction in sap flow density during the dry period.

Combining dynamic variables (phenology, regulation of transpiration, leaf water potential), architecture characteristics (rooting pattern) and intrinsic functional traits (vulnerability to cavitation) allowed us to define five contrasted clusters of trees in terms of response strategy to soil water depletion that statistically correspond to the five studied species (Fig. 4b). The location of the clusters on the factorial plane suggests a gradient of drought response strategies among these co-existing broad-leaved species and points to ecological niche differentiation and water resource partitioning (Tilman 1982). We clearly observed functional similarities among $Q$. robur, $S$. capreae, $F$. sylvatica and $C$. betulus along the first factorial axis, while $B$. pendula is clearly distant from those species, and three distinct groups of species along the second factorial axis: (a) $Q$. robur and $S$. capreae, (b) B. pendula and (c) F. sylvatica and $C$. betulus. Based on these axes, three different response strategies to soil water depletion among these co-occurring species can be highlighted:

1. Q. robur and S. capreae can be characterised as drought avoidance species (sensu Kramer 1983) as they possess a deep root system and high (less negative) $\Psi_{\mathrm{wp}}$ under 
dry soil conditions. They therefore do not seem to strongly experience soil drought and consequently show a limited decrease in SFD\% over the dry period. These species are also characterised by an intermediate growing season length and by xylem tissues which are rather vulnerable to cavitation, especially $S$. capreae $\left(\Psi_{50}=\right.$ $-1.6 \mathrm{MPa}$ ). In $S$. capreae, at the end of the dry period, high embolism levels were reached (close to $60 \%$, data not shown), while stomatal regulation was not initiated (Fig. 2a, b). Such behaviour is similar to that reported for Populus euphratica, a species growing along river banks in arid regions of Central Asia (Hukin et al. 2005). This species is characterised by a higher vulnerability to drought-induced cavitation than other species of Populus, which can lead to important embolism levels (Hukin et al. 2005).

2. B. pendula displays a different response to soil water depletion than the two species in the previous group. Even though the rooting system of $B$. pendula explores deep soil layers, we observed a strong decrease in both SFD $\%$ and $\Psi_{\mathrm{wp}}$ during the summer drought, while $\Psi_{\mathrm{wm}}$ remained rather constant. This pattern typically recalls the isohydric behaviour in leaf transpiration control described by Tardieu and Simonneau (1998), which implies efficient stomatal regulation when soil water depletion starts. This regulation is probably mediated by chemical messengers (e.g. ABA) (Tyree and Yang 1990) that fine roots growing in the upper soil layers may synthesize when they encounter a rapid decrease in soil water availability at the onset of the dry summer (Martin-Vertedor and Dodd 2011). Our results suggest that $B$. pendula does not really avoid soil drought despite its deep rooting capacity. This hypothesis is also supported by the fact that this species is highly vulnerable to cavitation in the twigs $\left(\Psi_{50}=-1.8 \mathrm{MPa}\right)$. Furthermore, as the roots of Betulus species have higher vulnerability to cavitation than do the twigs (Sperry and Saliendra 1994), one can hypothesize that the fine roots of $B$. pendula are subject to cavitation early when soil water depletion first occurs, leading to stomatal closure. Nevertheless, the earliness of budburst and the shorter growing season compared to some other species allows $B$. pendula to display high annual growth rate.

3. C. betulus and F. sylvatica both displayed typical characteristics of drought-sensitive species, unable to avoid soil drought. These results are consistent with the strong stomatal regulation observed for $F$. sylvatica during the exceptional drought in the summer of 2003 (Granier et al. 2007). Both species have a shallow root system; they showed the highest resistance to drought-induced cavitation and a stronger reduction in transpiration with soil water depletion compared to the three drought-avoiding species (1).

\section{Conclusions}

Our study highlights contrasted drought response strategies among co-occurring and competing tree species in a mesic environment frequently submitted to summer droughts. For the five studied species, we showed a trade-off between leaf phenology, resistance of xylem to cavitation and root system depth, as had previously been observed in xeric habitats. In the mesic environment we studied, a deep root system allowing access to available water when superficial soil layers dry out during summer droughts seems to be a key functional trait for the species to cope with drought. Indeed, deep roots allow the plant to limit stomatal regulation during dry periods and thus to potentially maintain high levels of carbon assimilation and growth. However, our results only address the short term impact of water stress on tree species water acquisition and use; they do not reflect possible delayed effects such as the mobilisation of stored reserves for growth under limiting soil water levels. Furthermore, our study was conducted in a young regenerating stand (15 to 25 years old), and mature trees may have different response patterns since the root systems of some species are likely to extend to deeper soil layers. Hence, further long-term, comprehensive observations are needed to elaborate functional models that can simulate mixed species forest ecosystem response to global environmental changes and lead to improved management in temperate naturally regenerating mixed stands.

Acknowledgments We would like to thank Hervé Cochard, Têté Severin Barigah and Marie-Béatrice Bogeat Triboulot for their advice regarding cavitation measurements. We are also grateful to Rémi Wortemann for his help with the measurements and to Bernard Clerc, Pascal Courtois, Patrick Gross and Jean-Marie Gioria for their technical support and assistance in field. The financial support for this research was provided by the French program Ecoger. MZ was supported by a Doctoral fellowship from the French Ministry of Research.

\section{References}

Aussenac G, Finkelstein D (1983) Influence de la sécheresse sur la croissance et la photosynthèse du cèdre. Ann For Sci 40:67-77

Bodin P, Wiman B (2007) The usefulness of stability concepts in forest management when coping with increasing climate uncertainties. Forest Ecol Manag 242:541-552

Bréda N, Granier A (1996) Intra- and Inter-annual variations of transpiration, leaf area index and radial growth of a sessile oak stand (Quercus petraea). Ann For Sci 53:521-536

Bréda N, Cochard H, Dreyer E, Granier A (1993a) Water transfer in a mature oak stand (Quercus petraea): seasonal evolution and effects of a severe drought. Can J For Res 23:1136-1143

Bréda N, Cochard H, Dreyer E, Granier A (1993b) Field comparison of transpiration, stomatal conductance and vulnerability to cavitation of Quercus petraea and Quercus robur under water stress. Ann For Sci 50:571-582 
Bréda N, Granier A, Barataud F, Moyne C (1995) Soil water dynamics in oak stand. I. soil moisture, water potentials, and water uptake by roots. Plant Soil 172:17-27

Bréda N, Huc R, Granier A, Dreyer E (2006) Temperate forest trees and stands under severe drought: a review of ecophysiological responses, adaptation processes and long-term consequences. Ann For Sci 63:625-644

Cochard H, Cruiziat P, Tyree MT (1992) Use of positive pressures to establish vulnerability curves. Further support for the air seeding hypothesis and implications for pressure-volume analysis. Plant Physiol 100:205-209

Cochard H, Lemoine D, Dreyer E (1999) The effects of acclimation to sunlight on the xylem vulnerability to embolism in Fagus sylvatica L. Plant Cell Environ 22:101-108

Coners H, Leuschner C (2002) In situ water absorption by tree fine roots measured in real time using miniature sap-flow gauges. Funct Ecol 16:696-703

Gould PJ, Harrington CA, St. Clair JB (2011) Incorporating genetic variation into a model of budburst phenology of coast Douglas-fir (Pseudotsuga menziesii var. menziesii). Can J For Res 41:139-150

Granier A (1985) Une nouvelle méthode pour la mesure de flux de sève brute dans le tronc des arbres. Ann For Sci 42:193-200

Granier A, Bréda N, Biron P, Villette S (1999) A lumped water balance model to evaluate duration and intensity of drought constraints in forest stands. Ecol Model 116:269-283

Granier A, Reichstein M, Bréda N, Janssens I, Falge E, Ciais P, Grünwald T, Aubinet M, Berbigier P, Bernhofer C, Buchmann N, Facini O, Grassi G, Heinesch B, Ilvesniemi H, Keronen P, Knohl A, Kostner B, Lagergren F, Lindroth A, Longdoz B, Loustau D, Mateus J, Montagnani L, Nys C, Moors E, Papale D, Peiffer M, Pilegaard K, Pita G, Pumpanen J, Rambal S, Rebmann C, Rodrigues A, Seufert G, Tenhunen J, Vesala T, Wang Q (2007) Evidence for soil water control on carbon and water dynamics in European forests during the extremely dry year: 2003. Agri For Met 143:123-145

Hacke U, Sperry F, Pockman W, Davis S, McCulloh K (2001) Trends in wood density and structured are linked to prevention of xylem implosion by negative pressure. Oecol 126:457-461

Holscher D, Koch O, Korn S, Leuschner C (2005) Sap flux of five cooccurring tree species in a temperate broad-leaved forest during seasonal soil drought. Trees Struct Funct 19:628-637

Hsiao TC, Acevedo E, Fereres E, Henderson DW (1976) Water stress, growth, and osmotic adjustment. Phil Trans R Soc Lond B 26:479-500

Hukin D, Cochard H, Dreyer E, Le Thiec D, Bogeat-Triboulot M (2005) Cavitation vulnerability in roots and shoots: does Populus euphratica Oliv., a poplar from arid areas of central Asia, differ from other poplar species. J Exp Bot 56:2003-2010

Kocher P, Gebauer T, Horna V, Leuschner C (2009) Leaf water status and stem xylem flux in relation to soil drought in five temperate broad-leaved tree species with contrasting water use strategies. Ann For Sci 66:101. doi:10.1051/forest:2008076

Kramer P (1983) Drought tolerance and water use efficiency. In: Water relations of plants. Academic, New York, pp 390-415

Lacaze J (2000) Forest management for recreation and conservation: new challenges. Forestry 73:137-141
Leuschner C, Coners H, Icke R (2004) In situ measurement of water absorption by fine roots of three temperate trees: species differences and differential activity of superficial and deep roots. Tree Physiol 24:1359-1367

Leuzinger S, Zotz G, Asshoff R, Korner C (2005) Responses of deciduous forest trees to severe drought in central Europe. Tree Physiol 25:641-650

Martin-Vertedor AI, Dodd IC (2011) Root-to-shoot signalling when soil moisture is heterogeneous: increasing the proportion of root biomass in drying soil inhibits leaf growth and increases leaf abscisic acid concentration. Plant Cell Environ 34:1164-1175

McDowell N, Pockman W, Allen C, Breshears D, Cobb N, Kolb T, Plaut J, Sperry J, West A, Williams D, Yepez E (2008) Mechanisms of plant survival and mortality during drought: why do some plants survive while others succumb to drought? New Phytol 178:719-739

Pammenter N, Vander Willigen C (1998) A mathematical and statistical analysis of the curves illustrating vulnerability of xylem to cavitation. Tree Physiol 18:589-593

Pataki D, Oren R, Smith W (2000) Sap flux of co-occurring species in a western subalpine forest during seasonal soil drought. Ecol $81: 2557-2566$

Schär C, Vidale P, Lüthi D, Frei C, Häberli C, Liniger M, Appenzeller C (2004) The role of increasing temperature variability in European summer heatwaves. Nature 427:332-336

Sperry J, Hacke U (2002) Desert shrub water relations with respect to soil characteristics and plant functional type. Funct Ecol 16:367378

Sperry J, Saliendra N (1994) Intra and inter-plant variation in xylem cavitation in Betula occidentalis. Plant Cell Environ 17:12331241

Sperry J, Hacke U, Oren R, Comstock J (2002) Water deficits and hydraulic limits to leaf water supply. Plant Cell Environ 25:251263

Tardieu F, Simonneau T (1998) Variability among species of stomatal control under fluctuating soil water status and evaporative demand: modelling isohydric and anisohydric behaviors. J Exp Bot 49:419-432

Thomas FM, Hartmann G (1998) Tree rooting patterns and soil water relations of healthy and damaged stands of mature oak (Quercus robur L. and Quercus petraea [Matt] Liebl). Plant Soil 203:145158

Tilman D (1982) Resource competition and community structure, Number 17. Princeton University Press, Princeton

Tyree MT, Cochard H (1996) Summer and winter embolism in oak: impact of water relations. Ann For Sci 53:173-180

Tyree MT, Yang S (1990) Water storage capacity of Thuja, Tsuga and Acer stems measured by dehydration isotherms. Planta 182:420 426

Zapater M, Hossann C, Bréda N, Bréchet C, Bonal D, Granier A (2011) Evidence of hydraulic lift in a young beech and oak mixed forest using ${ }^{18} \mathrm{O}$ soil water labelling. Trees Struct Funct 24:885894

Zhang Y, Chen HYH, Reich PB (2012) Forest productivity increases with evenness, species richness and trait variation: a global metaanalysis. J Ecol 100:742-749 